\title{
Potential of Fermented Fruit Peel Liquid in Cosmetics as a Skin Care Agent
}

\author{
Do Tan Khang ${ }^{1} \mathbb{D}$, Le Thi Thuy Tien ${ }^{1}$, Tran Thanh Men ${ }^{2} \mathbb{D}$ and Nguyen Phuong Thuy ${ }^{3, *}$ \\ 1 Biotechnology Research and Development Institute, Can Tho University, Can Tho City 94000, Vietnam; \\ dtkhang@ctu.edu.vn (D.T.K.); letien2504@gmail.com (L.T.T.T.) \\ 2 College of Natural Sciences, Can Tho University, Can Tho City 94000, Vietnam; ttmen@ctu.edu.vn \\ 3 School of Agriculture and Aquaculture, Tra Vinh University, Tra Vinh City 87000, Vietnam \\ * Correspondence: npthuy@tvu.edu.vn
}

Citation: Khang, D.T.; Tien, L.T.T.; Men, T.T.; Thuy, N.P. Potential of Fermented Fruit Peel Liquid in Cosmetics as a Skin Care Agent. Cosmetics 2021, 8, 33

https://doi.org/10.3390/ cosmetics 8020033

Academic Editor: Lucia Panzella

Received: 31 March 2021

Accepted: 28 April 2021

Published: 4 May 2021

Publisher's Note: MDPI stays neutra with regard to jurisdictional claims in published maps and institutional affiliations.

Copyright: (c) 2021 by the authors. Licensee MDPI, Basel, Switzerland. This article is an open access article distributed under the terms and conditions of the Creative Commons Attribution (CC BY) license (https:/ / creativecommons.org/licenses/by/ $4.0 /)$.

\begin{abstract}
The purpose of this study was to evaluate the antioxidant, antibacterial, and anti-UVB of three kinds of fermented fruit peel extracts by pectinase enzyme, including pomegranate, pomelo, and banana peel. The antioxidant was evaluated by the DPPH (2,2-Diphenyl-1-picrylhydrazyl) free radical scavenging method. Antibacterial activity against Escherichia coli and Staphylococcus aureus was assessed by disk diffusion assay, and the photoprotective activity was measured using a photospectrometric method. The results revealed that pomegranate peel extract at $3000 \mathrm{IU} / \mathrm{g}$ peel exhibited potent free radical scavenging property against $\mathrm{DPPH}$, with the smallest $\mathrm{IC}_{50}$ value at $0.18 \%$, which was better than that of pomelo peel extract at $55.79 \%$. Furthermore, the results suggested that the pomegranate peel extract also exhibited antibacterial activity against $E$. coli better than pomelo peel extract, but none of the three samples shows the antibacterial capacity against $S$. aureus. Moreover, $10 \%$ pomegranate peel extract also expressed the strongest anti-UVB activity, with an SPF value of 36.582. The research demonstrates pomegranate peel's bioactivity potential for further experiments.
\end{abstract}

Keywords: antibacterial activity; antioxidant activity; anti-UVB activity; fermented fruit peel; pectinase

\section{Introduction}

People all around the world consume a huge amount of fruit every year. Much research has demonstrated the importance of fruit peels in a variety of aspects, such as fertilizer, biofuel, enzymes, food, or cosmetics. There were about 102 million tons of banana consumed in 2018, and the peel represents the $35 \%$ of the weight. Traditionally, banana peel waste has been used as a medicinal source for the treatment of anemia, diabetes, inflammation, and cancer, due to its high amount of phenolic and fiber [1]. Moreover, pomelo peel contains many bioactive compounds, such as coumarins and flavonoids, polyphenols, and vitamins, that impact health benefits beyond basic nutrition [2]. According to Zhai et al. [3], pomegranate is a popular fruit with a variety of products, such as juice, wine, and jam, in which its peel contains a large amount of phenolics, flavonoids, and tannins, which are commonly used in medicine.

Pectin is a heteropolysaccharide that contributes to the plant cell structure and has been applied in food and pharmaceuticals. It is mainly composed of $\alpha-1-4 \mathrm{~d}$-galacturonic acid and some neutral sugars, which have been demonstrated to be safe in cosmetics [4]. However, there has been a limited application of these substances in cosmetic discipline. The extraction of fermented fruit peel is targeted to promote economic value, maximize the application of agricultural products, and minimize waste into the environment. The study aims to compare the antioxidant, antibacterial, and anti-UVB abilities of three fermented fruit peel extracts, including pomegranate, pomelo, and banana peel by pectinase enzyme. 


\section{Materials and Methods}

\subsection{Materials}

The study was conducted in the Biotechnology Research and Development Institute at Can Tho University from August to December 2020. Fresh pomegranate (PGP), pomelo (PP), and banana (BP) were purchased at local market in Can Tho city. The fruit peels then were washed with tap water and rinse with distilled water, then cut into smaller sizes (about 3-5 mm) to prepare for next experiments. Escherichia coli (ATCC 25922) and Staphylococcus aureus (ATCC 25923) were supplied by Laboratory of Molecular Biotechnology, Biotechnology Research and Development Institute.

\subsection{Methods}

\subsubsection{Preparation of Fermented Fruit Peel Extract}

The experiment used for fermentation was a modified version of that conducted by Pocan et al. [5]. Six grams of the sample was dispensed in $100 \mathrm{~mL}$ of sodium citrate buffer ( $\mathrm{pH} 4.8$ ) in a $250 \mathrm{~mL}$ capacity Erlenmeyer flask. Different weights of pectinase enzyme powder were added corresponding to the observed concentration: 1000, 3000, and $6000 \mathrm{IU} / \mathrm{g}$. A treatment without enzyme was also conducted to evaluate enzyme activity. The mixture was stirred lightly, then allowed to incubate and shake for $24 \mathrm{~h}$ at $50{ }^{\circ} \mathrm{C}, 150 \mathrm{rpm}$. After fermentation, the samples were incubated in boiled water at $95^{\circ} \mathrm{C}$ for $5 \mathrm{~min}$ to inactivate the enzyme. Finally, the supernatant obtained was filtered through a filter paper and stored at $5{ }^{\circ} \mathrm{C}$. All the experiments were conducted from this supernatant.

\subsubsection{Antioxidant Activity}

DPPH (2,2-diphenyl-1-picrylhydrazyl) free radical scavenging assay was performed using the method of Trang et al. [6]. In short, each concentration of samples diluted with methanol were mixed appropriately with DPPH dissolved in methanol with the ratio $100 \mu \mathrm{L}$ sample/100 $\mu \mathrm{L}$ DPPH. The diluted concentrations of each fruit peel were different due to the color of the liquid. After reacting in dark at room temperature for $40 \mathrm{~min}$, the absorbance of mixture was measured at $517 \mathrm{~nm}$, using methanol as the blank, and ascorbic acid was used as positive control. Percent inhibition was calculated, and a graph between the concentration and \% inhibition was plotted to obtain the $\mathrm{IC}_{50}$. Radical scavenging activity was calculated using the following formula:

$$
\frac{\left(A_{c S}-A_{\text {Blank 1 }}\right)-\left(A_{S}-A_{\text {Blank } 2}\right)}{\left(A_{c s}-A_{\text {Blank 1 }}\right)}
$$

where $A_{c S}$ is the absorbance of the control reaction (methanol + DPPH); $A_{s}$ is the absorbance in the presence of sample; $A_{\text {Blank } 1}$ is the absorbance of Blank 1 , containing only methanol; and $A_{\text {Blank } 2}$ is the absorbance of Blank 2, containing only the sample.

\subsubsection{Antibacterial Activity}

The antibacterial assay was performed using a disk diffusion assay described by Wiegand et al. [7] with adjustment. Briefly, the density of bacteria was standardized to $10^{6}-10^{7} \mathrm{CFU} / \mathrm{mL}$, and was swabbed onto the agar surface. Then, $25 \mu \mathrm{L}$ of samples with different concentration was loaded onto sterile blank disk $(7 \mathrm{~mm})$. After drying, the discs were then impregnated with inoculated agar. Sodium citrate $(0.05 \mathrm{M})$ and streptomycin $(1 \mathrm{mg} / \mathrm{mL})$ served as the negative and positive control, respectively. The plates were left for $15 \mathrm{~min}$ to allow the diffusion of samples, before being incubated at $37^{\circ} \mathrm{C}$ for $24 \mathrm{~h}$. Antibacterial activity was observed when the inhibition zone was measured.

\subsubsection{Anti-UVB Activity}

The anti-UV activity of fermented fruit peel extracts were measured by in vitro determination of sun protection factor (SPF), which is considered to be one of the most frequently used indicators for the classification of protection levels afforded by sunscreen products 
against sunburn, which is due mainly to harmful UV-B radiation. Spectrophotometric scanning was performed at wavelengths between 290 and $320 \mathrm{~nm}$, with intervals of $5 \mathrm{~nm}$, using a spectrophotometer. The SPF value was obtained according to the equation developed by Mansur et al. [8]:

$$
\mathrm{SPF}=\mathrm{CF} \sum_{290}^{320} \mathrm{EE}(\lambda) \mathrm{I}(\lambda) \mathrm{A}(\lambda)
$$

where $\operatorname{EE}(\lambda)$ is the erythemal effect spectrum, $I(\lambda)$ is the solar intensity spectrum, $A(\lambda)$ is the absorbance, and CF is the correction factor (10).

The values of $\operatorname{EE}(\lambda) \times \mathrm{I}(\lambda)$ are constants, and they were determined by Sayre et al. [9], as shown in Table 1.

Table 1. $\mathrm{EE}(\lambda) \times \mathrm{I}(\lambda)$ values used in calculation of sun protection factor (SPF).

\begin{tabular}{cc}
\hline Wavelength $(\mathbf{n m})$ & $\mathbf{E E} \times \mathbf{I}$ \\
\hline 290 & 0.0150 \\
295 & 0.0817 \\
300 & 0.2874 \\
305 & 0.3278 \\
310 & 0.1864 \\
315 & 0.0839 \\
320 & 0.0180 \\
\hline
\end{tabular}

\subsubsection{Statistical Analysis}

The data were analyzed by using Minitab 16.0 software (Coventry, UK) and displayed as means \pm SE in triplicate. One-way analysis of variance (ANOVA) and Tukey tests were conducted to determine significant differences, and means were considered as statistically significant if $p<0.05$.

\section{Results and Discussion}

\subsection{Production of Fermented Fruit Peel Extracts}

After fermentation, the recovery volume of each fermented fruit peel was $90 \mathrm{~mL}$. The $\mathrm{pH}$ value of these solutions have changed during the process, which were shown in Table 2.

Table 2. The $\mathrm{pH}$ values of fermented fruit peel extracts.

\begin{tabular}{cccc}
\hline Enzyme & \multicolumn{3}{c}{ pH Value } \\
\hline Concentration & PGP & PP & BP \\
\hline $1000 \mathrm{IU}$ & $4.97^{\mathrm{b}} \pm 0.03$ & $4.79^{\mathrm{de}} \pm 0.02$ & $5.03^{\mathrm{a}} \pm 0.02$ \\
$3000 \mathrm{IU}$ & $4.86^{\mathrm{c}} \pm 0.01$ & $4.7^{\mathrm{f}} \pm 0.02$ & $5.01^{\mathrm{ab}} \pm 0.01$ \\
$6000 \mathrm{IU}$ & $4.73^{\mathrm{f}} \pm 0.02$ & $4.77^{\mathrm{ef}} \pm 0.02$ & $5.037^{\mathrm{a}} \pm 0.01$ \\
0 & $4.84^{\mathrm{cd}} \pm 0.01$ & $4.78^{\mathrm{e}} \pm 0.01$ & $4.97^{\mathrm{e}} \pm 0.01$ \\
\hline $\mathrm{CV}$ & & 2.38
\end{tabular}

Note: values (mean $\pm \mathrm{SD}$ ) in the table are the average values of triplications. The average values with the same letter are not significant at 95\% probability, based on a Tukey test. PGP: pomegranate peel; PP: pomelo peel; BP: banana peel; $\mathrm{CV}$ : coefficient of variation.

The results after fermentation indicated $\mathrm{pH}$ alternation in all of the extracts. There was a slight decrease in $\mathrm{pH}$ of pomelo peel (PP) to about 4.73-4.79 compare to the initial $\mathrm{pH}$ of 4.8, whereas pomegranate peel (PGP) and banana peel (BP) increased from about 4.84 to 5.03 . The differences in final products after fermentation could lead to the changes in $\mathrm{pH}$ value of the solutions.

The mass of three fruit peels after fermentation were dried until reaching a constant value, and weighed to evaluate the correlation between enzyme concentration and degradation process (Table 3). The results revealed that the mass of PGP and PP decreased when increasing enzyme concentration, whereas the reverse was true for BP. 
Table 3. Mass of constant dried samples after fermentation.

\begin{tabular}{cccc}
\hline \multirow{2}{*}{$\begin{array}{c}\text { Enzyme } \\
\text { Concentration }\end{array}$} & PGP & Weight (g) \\
\cline { 2 - 4 } & $1.68^{\mathrm{ab}} \pm 0.02$ & $1.38^{\mathrm{fg}} \pm 0.01$ & BP \\
\hline $1000 \mathrm{IU}$ & $1.64^{\mathrm{bc}} \pm 0.02$ & $1.37^{\mathrm{fg}} \pm 0.02$ & $1.39^{\mathrm{f}} \pm 0.02$ \\
$3000 \mathrm{IU}$ & $1.54^{\mathrm{d}} \pm 0.01$ & $1.35^{\mathrm{g}} \pm 0.01$ & $1.46^{\mathrm{e}} \pm 0.02$ \\
$6000 \mathrm{IU}$ & $1.72^{\mathrm{a}} \pm 0.02$ & $1.63^{\mathrm{c}} \pm 0.02$ & $1.37^{\mathrm{e}} \pm 0.01$ \\
0 & & 8.77 & 1.02 \\
\hline $\mathrm{CV}$ & &
\end{tabular}

Note: values (mean \pm SD) in the table are the average values of triplications. The average values with the same letter are not significant at $95 \%$ probability, based on a Tukey test. PGP: pomegranate peel; PP: pomelo peel; BP: banana peel; CV: coefficient of variation.

\subsection{Antibacterial Activity}

The antimicrobial property of three fermented fruit peel extracts against $E$. coli and S. aureus were estimated by the diameter of inhibition zone, illustrated in Figure 1 and Table 4.

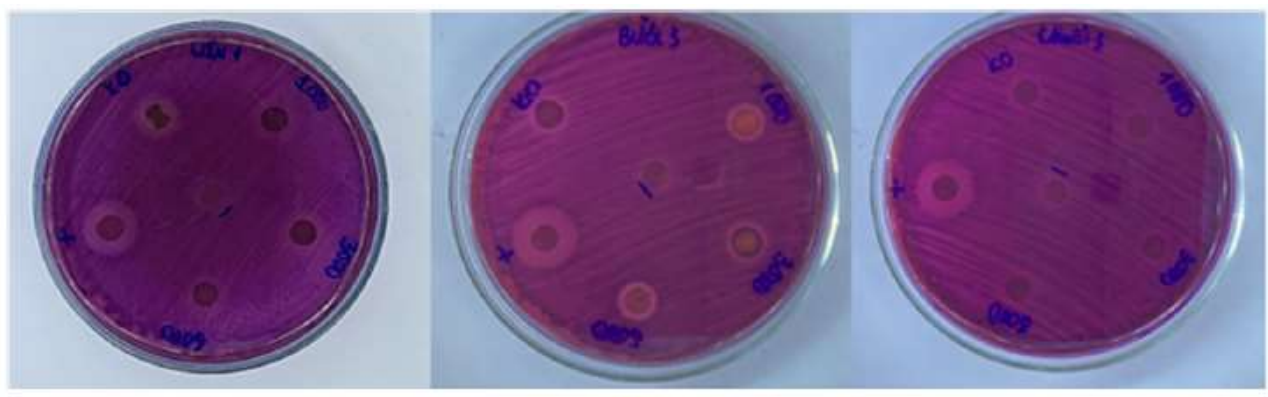

A

B

C

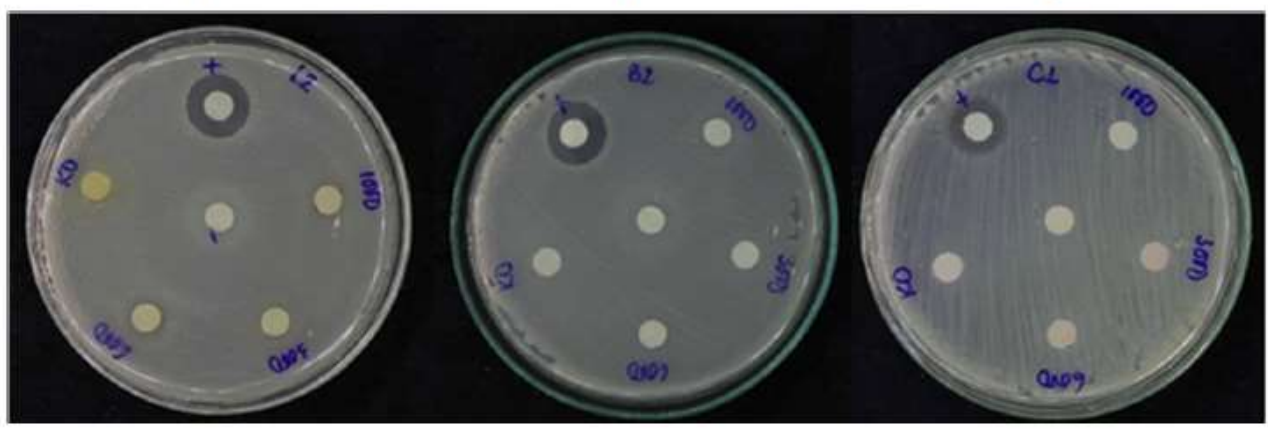

Figure 1. Inhibition zone of three fermented fruit peel extracts against $E$. coli (purple medium) and $S$. aureus (white medium) bacteria (mm). (A) Pomegranate peel; (B) pomelo peel; (C) banana peel.

The results reveal that among the three fruit peel extracts, PGP extract possessed potent antibacterial activity against $E$. coli. The highest value was reported in the treatment without enzyme, with the range of $7.33 \mathrm{~mm}$, which was significantly different from the other fruit peel extracts ( $p<0.05$ by Tukey test). The PP extract showed an inhibition zone smaller than PGP, ranging from 1.67 to $2.33 \mathrm{~mm}$, and the treatment without enzyme showed no inhibitory effect on this bacteria strain. BP extract showed no effect on bacteria growth at any enzyme concentration. It also indicated a slight decline with no significant difference of inhibition zone diameter when increasing enzyme concentration. During fermentation, the production of galacturonic acid and some neutral sugars not only possessed inhibition activity, but also promoted bacteria growth. On the contrary, none of the extracts showed any capacity at any concentrations against $S$. aureus. 
Table 4. Inhibition zone of three fermented fruit peel extracts.

\begin{tabular}{ccc}
\hline \multirow{2}{*}{ Sample } & \multicolumn{2}{c}{ Diameter of Inhibition Zone $(d) \pm$ SD $(\mathbf{m m})$} \\
\cline { 2 - 3 } & \multicolumn{1}{c}{ E. coli } & S. aureus \\
\hline PGP-1000 IU & $5.33^{\mathrm{c}} \pm 0.57$ & - \\
PGP-3000 IU & $6.67^{\mathrm{bc}} \pm 0.57$ & - \\
PGP-6000 IU & $5.33^{\mathrm{c}} \pm 0.57$ & - \\
PGP-0 IU & $7.33^{\mathrm{b}} \pm 0.57$ & - \\
PP-1000 IU & $2.33^{\mathrm{d}} \pm 057$ & - \\
PP-3000 IU & $2.33^{\mathrm{d}} \pm 0.57$ & - \\
PP-6000 IU & $1.67^{\mathrm{d}} \pm 0.57$ & - \\
PP-0 IU & - & - \\
BP-1000 IU & - & - \\
BP-3000 IU & - & - \\
BP-6000 IU & - & - \\
BP-0 IU & - & $4.67 \pm 0.57$ \\
Buffer & - &
\end{tabular}

Note: values (mean \pm SE) in the table are the average values of triplications. The average values with the same letter in the same column are not significant at $95 \%$ probability based on a Tukey test. PGP: pomegranate peel; PP: pomelo peel; BP: banana peel; CV: coefficient of variation.

\subsection{Antioxidant Activity}

PGP showed antioxidant capacity, as indicated by the dependent increase of the sample concentration being significantly different in percentage inhibition. The treatment without enzyme at a concentration of $1 \%$ exhibited the highest DPPH radical scavenging efficiency at $86.67 \%$, comparing to the lowest percentage of inhibition, which was observed in the same treatment at a concentration of $0.25 \%(30.2 \%$; Table 5$)$.

Table 5. DPPH free radical scavenging activity of pomegranate peel.

\begin{tabular}{cccccc}
\hline $\begin{array}{c}\text { Enzyme } \\
\text { Concentration }\end{array}$ & \multicolumn{7}{c}{ Diluted Concentration (\%) } \\
\hline (IU/g Peel) & $\mathbf{0 . 2 5}$ & $\mathbf{0 . 3 5}$ & $\mathbf{0 . 5}$ & $\mathbf{0 . 7 5}$ & $\mathbf{1}$ \\
\hline \multicolumn{7}{c}{ DPPH Radical Scavenging Ability (\%) } \\
\hline 1000 & $33.63^{\mathrm{k}} \pm 0.51$ & $44.59^{\mathrm{h}} \pm 0.36$ & $53.37^{\mathrm{f}} \pm 1.54$ & $72.70^{\mathrm{c}} \pm 0.28$ & $78.68^{\mathrm{b}} \pm 0.48$ \\
3000 & $39.53^{\mathrm{i}} \pm 1.04$ & $48.24^{\mathrm{g}} \pm 0.28$ & $62.53^{\mathrm{e}} \pm 1.42$ & $74.56^{\mathrm{c}} \pm 0.43$ & $80.55^{\mathrm{b}} \pm 0.81^{\mathrm{b}}$ \\
6000 & $32.94^{\mathrm{k}} \pm 0.04$ & $40.48^{\mathrm{i}} \pm 0.35$ & $50.31^{\mathrm{g}} \pm 1.15$ & $68.63^{\mathrm{d}} \pm 0.67$ & $78.26^{\mathrm{b}} \pm 0.22$ \\
0 & $30.2^{\mathrm{l}} \pm 1.48$ & $36.17^{\mathrm{j}} \pm 0.13$ & $55.24^{\mathrm{f}} \pm 0.72$ & $70.20^{\mathrm{d}} \pm 0.73$ & $86.67^{\mathrm{a}} \pm 0.59$ \\
\hline CV & & & 31.74 & &
\end{tabular}

Note: values (mean \pm SE) in the table are the average values of triplications. The average values with the same letter are not significant at $95 \%$ probability, based on a Tukey test. CV: coefficient of variation.

In general, the PP extracts showed a tendency to quench DPPH free radicals in all treatments (Table 6). In comparison, there was almost no significant difference in the proportion inhibition of three enzyme concentration treatments when increasing solution concentration. In addition, the treatment without enzyme had weaker reducing power than that in the remaining treatments. 
Table 6. DPPH free radical scavenging activity of pomelo peel.

\begin{tabular}{ccccc}
\hline $\begin{array}{c}\text { Enzyme } \\
\text { Concentration }\end{array}$ & \multicolumn{5}{c}{ Diluted Concentration (\%) } \\
\hline (IU/g Peel) & $\mathbf{2 0}$ & \multicolumn{4}{c}{$\mathbf{4 0}$} & $\mathbf{8 0 ~ 1 0 0}$ \\
\hline \multicolumn{5}{c}{ DPPH Radical Scavenging Ability (\%) } \\
\hline 1000 & $32.47^{\mathrm{h}} \pm 1.82$ & $48.17^{\mathrm{e}} \pm 0.13$ & $76.46^{\mathrm{b}} \pm 1.98$ & $82.47^{\mathrm{a}} \pm 0.23$ \\
3000 & $32.29^{\mathrm{h}} \pm 0.54$ & $48.62^{\mathrm{e}} \pm 1.26$ & $77.17^{\mathrm{b}} \pm 0.58$ & $82.24^{\mathrm{a}} \pm 0.46$ \\
6000 & $38.08^{\mathrm{g}} \pm 0.85$ & $52.44^{\mathrm{d}} \pm 0.49$ & $77.04^{\mathrm{b}} \pm 0.79$ & $83.54^{\mathrm{a}} \pm 0.66$ \\
0 & $32.65^{\mathrm{h}} \pm 0.65$ & $45.37^{\mathrm{f}} \pm 0.58$ & $65.19^{\mathrm{c}} \pm 0.07$ & $64.32^{\mathrm{c}} \pm 0.18$ \\
\hline \multicolumn{5}{c}{32.6} \\
\hline
\end{tabular}

Note: values (mean \pm SE) in the table are the average values of triplications. The average values with the same letter are not significant at $95 \%$ probability, based on a Tukey test. CV: coefficient of variation.

The highest percentage of antioxidant activity for BP was observed in $6000 \mathrm{IU} / \mathrm{g}$ peel: $85.93 \%$ at $100 \%$ sample concentration (Table 7). In addition, the treatment without enzyme also indicated good antioxidant potential similar to $6000 \mathrm{IU} / \mathrm{g}$ peel treatment with no significant difference at all concentration.

Table 7. DPPH free radical scavenging activity of banana peel.

\begin{tabular}{ccccc}
\hline $\begin{array}{c}\text { Enzyme } \\
\text { Concentration }\end{array}$ & \multicolumn{5}{c}{ Diluted Concentration (\%) } \\
\hline (IU/g Peel) & $\mathbf{2 0}$ & $\mathbf{4 0}$ & $\mathbf{8 0}$ & $\mathbf{1 0 0}$ \\
\hline \multicolumn{5}{c}{ DPPH Radical Scavenging Ability (\%) } \\
\hline 1000 & $23.58^{1} \pm 0.65$ & $48.09^{\mathrm{i}} \pm 0.62$ & $77.74^{\mathrm{f}} \pm 0.33$ & $82.81^{\mathrm{bcd}} \pm 0.39$ \\
3000 & $28.16^{\mathrm{k}} \pm 0.51$ & $52.59^{\mathrm{h}} \pm 0.12$ & $82.15^{\mathrm{cde}} \pm 0.05$ & $80.24^{\mathrm{e}} \pm 0.38$ \\
6000 & $35.43^{\mathrm{j}} \pm 0.58$ & $58.71^{\mathrm{g}} \pm 0.41$ & $83.74^{\mathrm{bc}} \pm 0.32$ & $85.93^{\mathrm{a}} \pm 0.55$ \\
0 & $34.77^{\mathrm{j}} \pm 1.17$ & $57.35^{\mathrm{g}} \pm 0.24$ & $81.05^{\mathrm{de}} \pm 0.30$ & $84.33^{\mathrm{ab}} \pm 1.89$ \\
\hline \multicolumn{5}{c}{35.62} \\
\hline CV
\end{tabular}

Note: values (mean \pm SE) in the table are the average values of triplications. The average values with the same letter are not significant at $95 \%$ probability, based on a Tukey test. CV: coefficient of variation.

The ascorbic acid sample concentration-dependent increase was significantly different in its percentage inhibition (Table 8). The percentage inhibition was higher than $50 \%$ at the concentration of $20 \mu \mathrm{g} / \mathrm{mL}$.

Table 8. DPPH free radicals scavenging activity of ascorbic acid.

\begin{tabular}{cc}
\hline Concentration $(\boldsymbol{\mu g} / \mathbf{m L})$ & DPPH Radical Scavenging Ability (\%) \\
\hline 4 & $20.748^{\mathrm{h}} \pm 1.633$ \\
8 & $26.985^{\mathrm{g}} \pm 0.770$ \\
12 & $37.859^{\mathrm{f}} \pm 0.375$ \\
16 & $43.603^{\mathrm{e}} \pm 0.871$ \\
20 & $51.973^{\mathrm{d}} \pm 0.102$ \\
24 & $60.420^{\mathrm{c}} \pm 1.299$ \\
28 & $73.316^{\mathrm{b}} \pm 0.056$ \\
32 & $80.434^{\mathrm{a}} \pm 0.828$
\end{tabular}

Note: values (mean \pm SE) in the table are the average values of triplications. The average values with the same letter are not significant at $95 \%$ probability, based on a Tukey test.

\section{4. $I C_{50}$ Values}

PGP exhibited considerable potential for free radical scavenging activity, with the lowest $\mathrm{IC}_{50}$ value at $0.18 \%$. The other extracts showed moderate antioxidant ability, as indicated by the concentration-dependent increase in percentage inhibition. In particular, 
in $\mathrm{PP}$ and $\mathrm{BP}$ extract had $\mathrm{IC}_{50}$ value ranging from $37.98 \%$ to $55.79 \%$ and $34.69 \%$ to $49.12 \%$, respectively (Table 9).

Table 9. $\mathrm{IC}_{50}$ values of fermented fruit peel extracts and ascorbic acid.

\begin{tabular}{ccc}
\hline Sample & Regression Equation & IC $_{\mathbf{5 0}}$ \\
\hline PGP-1000 IU & $y=60.618 x+22.04\left(R^{2}=0.9592\right)$ & $0.46 \%$ \\
PGP-3000 IU & $y=54.742 x+29.88\left(R^{2}=0.9375\right)$ & $0.18 \%$ \\
PGP-6000 IU & $y=61.756 x+18.92\left(R^{2}=0.9864\right)$ & $0.50 \%$ \\
PGP-0 IU & $y=76.186 x+12.27\left(R^{2}=0.9834\right)$ & $0.49 \%$ \\
PP-1000 IU & $y=0.6414 x+21.40\left(R^{2}=0.9834\right)$ & $44.58 \%$ \\
PP-3000 IU & $y=0.6422 x+21.55\left(R^{2}=0.9782\right)$ & $44.31 \%$ \\
PP-6000 IU & $y=0.5776 x+28.12\left(R^{2}=0.9875\right)$ & $37.98 \%$ \\
PP-0 IU & $y=0.4192 x+26.61\left(R^{2}=0.9277\right)$ & $55.79 \%$ \\
BP-1000 IU & $y=0.7405 x+13.62\left(R^{2}=0.9588\right)$ & $49.12 \%$ \\
BP-3000 IU & $y=0.6687 x+20.66\left(R^{2}=0.9093\right)$ & $43.87 \%$ \\
BP-6000 IU & $y=0.6301 x+28.14\left(R^{2}=0.9346\right)$ & $34.69 \%$ \\
BP-0 IU & $y=0.6142 x+27.53\left(R^{2}=0.9416\right)$ & $36.59 \%$ \\
Ascorbic acid & $y=2.1593 x+10.55\left(R^{2}=0.9936\right)$ & $18.27 \mu \mathrm{g} / \mathrm{mL}$ \\
\hline
\end{tabular}

PGP: pomegranate peel; PP: pomelo peel; BP: banana peel.

\subsection{Anti-UVB Activity}

The results show that the PGP treatment of $1000 \mathrm{IU} / \mathrm{g}$ peel had the highest SPF value of 36.58 , about five times higher than the banana peel without enzyme treatment $(\mathrm{SPF}=7.43)$ at a concentration of $100 \%$. The SPF value of PGP tended to decrease from 36.58 to 28.82 when the enzyme concentration increased from 1000 to $6000 \mathrm{IU} / \mathrm{g}$ peel. In contrast, PP samples had a significant increase in SPF values from 26.84 to 29.28 when increasing enzyme concentration (Table 10).

Table 10. SPF values of three fermented fruit peel extracts.

\begin{tabular}{ccc}
\hline Sample & Concentration & SPF Value \\
\hline PGP-1000 IU & $10 \%$ & $36.58^{\mathrm{a}} \pm 0.03$ \\
PGP-3000 IU & $10 \%$ & $31.94^{\mathrm{b}} \pm 0.35$ \\
PGP-6000 IU & $10 \%$ & $28.82^{\mathrm{c}} \pm 0.03$ \\
PGP-0 IU & $10 \%$ & $36.16^{\mathrm{a}} \pm 0.48$ \\
PP-1000 IU & $100 \%$ & $26.84^{\mathrm{e}} \pm 0.41$ \\
PP-3000 IU & $100 \%$ & $27.71^{\mathrm{d}} \pm 0.12$ \\
PP-6000 IU & $100 \%$ & $29.28^{\mathrm{c}} \pm 0.14$ \\
PP-0 IU & $100 \%$ & $29.24^{\mathrm{c}} \pm 0.38$ \\
BP-1000 IU & $100 \%$ & $7.74^{\mathrm{g}} \pm 0.07$ \\
BP-3000 IU & $100 \%$ & $9.03^{\mathrm{f}} \pm 0.09$ \\
BP-6000 IU & $100 \%$ & $9.18^{\mathrm{f}} \pm 0.05$ \\
BP-0 IU & $100 \%$ & $7.43^{\mathrm{g}} \pm 0.02$ \\
\hline CV & 47.74 &
\end{tabular}

Note: values (mean $\pm \mathrm{SE}$ ) in the table were average values of triplications. The average values with the same letter were not significant at 95\% probability, based on a Tukey test. PGP: pomegranate peel; PP: pomelo peel; BP: banana peel; CV: coefficient of variation.

\section{Discussion}

This research focused on the preliminary biological activities of fermented fruit peels. Some compounds present in fruit peels, such as pectin, polyphenols, flavonoids, and terpenes, play an important role in fruit peel bioactivities. Ruangtong et al. [10] has synthesized a nano material by $\mathrm{ZnO}$ and banana peel extract applied in cancer treatment, thanks to the available bio-compounds. Pomegranate peels have been demonstrated as a valuable source of antioxidant compounds, with a high amount of ellagic acid and flavonoids [11]. In addition, pomelo peel essential oil has been widely used in traditional 
medicine. It contains many phytochemicals, such as terpenes, aldehydes, and ketones. Although many studies have verified the biological activities of fruit peels, the application of these natural materials are still limited.

The antibacterial property of three fermented fruit peel extracts were evaluated using two bacteria strains: E. coli and S. aureus. As shown in Table 4, most of the fermented fruit peel extracts did not shown the antimicrobial activity, except pomegranate peels. In contrast, some research has shown the antibacterial capacity of banana peels with different extracts. Mokbel et al. [12] reported the inhibition zone of ethyl acetate extract against $E$. coli and S. aureus to be $9 \pm 0.2$ and $12 \pm 0.4 \mathrm{~mm}$, respectively. In addition, different kinds of banana peel ethanol extract cultivated in Bali possess antibacterial activity against two bacteria strains, ranging from 11.00 to 14.77 and 9.00 to $13.37 \mathrm{~mm}$, respectively [13]. Another study on pomelo peel ethyl acetate extracts also indicated that the antibacterial effect on $E$. coli and S. aureus were 8.1 and $9.0 \mathrm{~mm}$, respectively, at $75 \mathrm{ppm}$ [14]. Different extraction methods might lead to obtaining different secondary metabolite compounds. These phytochemical contents provide an antibacterial property in different bacteria cytotoxic mechanisms, such as cell membranes, cell wall biosynthesis enzymes, protein synthesis, or nucleic acid replication repair, which acts via an anti-metabolite mechanism ([15]).

The importance of the antioxidant constituents from natural materials is raising interest among scientists; these antioxidants protect the body against reactive oxygen species (ROS). There was no correlation between enzyme concentration and antioxidant activity in PGP extract. It could be explained that antioxidant properties not only depend on antioxidants concentration, but also on the interaction and structure among antioxidants [16]. Therefore, increasing enzyme concentration does not totally lead to an increase in the synergism among bioactive compounds in the mixture.

Many previous studies have shown the antioxidant potential of dried fruit peels when extracting with different kinds of solvent, such as methanol $\left(\mathrm{IC}_{50}=1.7 \mu \mathrm{g} / \mathrm{mL}\right.$ in pomelo) and ethanol ( $\mathrm{IC}_{50}=0.37 \mu \mathrm{g} / \mathrm{mL}$ in banana) [17,18]. According to Castro-Vazquez et al. [19], several treatments, including far-infrared radiation, alkaline hydrolysis, enzyme treatment, and heat treatment, have been proposed to release more bioactive compounds from several species of citrus. Through this connection, it has been found that dried fruit peel extracts contain much higher concentrations of phenolic compounds than fresh ones, and hence exhibit greater antioxidant activity. Therefore, depending on the raw materials and methods, the results are different.

In the experiment, the antioxidant activity did not correlate with the enzyme concentration. Van Hung et al., [20] reported the antioxidant activity of pomelo peel powder, using enzyme-assisted powder with water extraction over $60 \mathrm{~min}$. It showed a lower DPPH scavenging ability compared with this study at any concentration $(28.6 \% \pm 1.1 \%)$. The studies of Ali et al. [17] and Fidrianny et al. [18] resulted in the $\mathrm{IC}_{50}$ values of PP extract and BP extract being $1.7 \mu \mathrm{g} / \mathrm{mL}$ and $0.37 \mu \mathrm{g} / \mathrm{mL}$, respectively, using dried peel with polar solvents. In ethanol extract, pomelo peels possess ability against oxidation, with an $\mathrm{IC}_{50}$ value of $68.55 \mu \mathrm{g} / \mathrm{mL}$ [21]. The free radical scavenging activity of fruit peel extracts vary among studies, depending on the origin of samples and extraction methods. According to Sun and Ho [16], the antioxidant properties not only depend on antioxidants concentration, but also on the interaction and structure among the antioxidants. Therefore, increasing enzyme concentration does not totally lead to an increase in synergism among bioactive compounds in the mixture.

UVB light has proven to be a principal factor causing skin cancer. UVB rays $(290-320 \mathrm{~nm})$ have been found to be 1000 times more likely to cause sunburn than UVA rays, leading to skin cancer and affecting genes. Phytochemicals from plant, such as phenolics and flavonoids, are considered as a conjugated aromatic system with the capacity to absorb UV light [22]. Punica granatum extract has widely applied as an oral supplement in skin care products, due to its potent photoprotection through the inhibition of free radicals or erythema and burning [23]. In this study, pomegranate peel expressed anti-UV capacity, with the SPF value higher than a commercial sunscreen (Dermatone) at the enzyme con- 
centration $1000 \mathrm{IU}$ and 10\% [24]. In addition, pomegranate peel methanol extracts have also resulted in the highest SPF value among B. monosperma flowers, $N$. cadamba leaves, P. granatum, and C. citratus leaf extracts (6.06 at $40.0 \mu \mathrm{g} / \mathrm{mL})$ [25]. Banana peel ethanol extract with bisulfite immersion has demonstrated potential skin protection, with an SPF value 10.67, slightly higher than our findings [26].

\section{Conclusions}

In this research, fermented pomegranate peel extract exhibited good bioactivity against oxidation, bacteria, and UVB light. In particular, pomegranate peel had the highest diameter of inhibition zone against $E$. coli, whereas the banana peel had no activity on this bacteria strain. The fermented pomegranate peel extract has potential as a skin care product, and should be further analyzed for clinical trials.

Author Contributions: Conceptualization, D.T.K. and L.T.T.T.; methodology, L.T.T.T.; formal analysis, T.T.M.; investigation, L.T.T.T. and D.T.K.; writing—original draft preparation, L.T.T.T.; writingreview and editing, D.T.K. and N.P.T.; supervision, N.P.T. All authors have read and agreed to the published version of the manuscript.

Funding: This research received no external funding.

Institutional Review Board Statement: Not applicable.

Informed Consent Statement: Not applicable.

Conflicts of Interest: The authors declare no conflict of interest.

\section{References}

1. Mathew, N.S.; Negi, P.S. Traditional uses, phytochemistry and pharmacology of wild banana (Musa acuminata Colla): A review. J. Ethnopharmacol. 2017, 196, 124-140. [CrossRef]

2. Salihan, N.H.A.B. Production of Rhamnose from Pomelo Peel Using Locally-Isolated Fungi Trametes sp. Ip3. Master's Thesis, Universiti Putra Malaysia, Seri Kembangan, Malaysia, 2016.

3. Zhai, X.; Zhu, C.; Li, Y.; Zhang, Y.; Duan, Z.; Yang, X. Optimization for pectinase-assisted extraction of polysaccharides from pomegranate peel with chemical composition and antioxidant activity. Int. J. Biol. Macromol. 2018, 109, 244-253. [CrossRef]

4. Fiume, M.M.; Bergfeld, W.F.; Belsito, D.V.; Hill, R.A.; Klaassen, C.D.; Liebler, D.C.; Marks, J.G., Jr.; Shank, R.C.; Slaga, T.J.; Snyder, P.W.; et al. Safety assessment of monosaccharides, disaccharides, and related ingredients as used in cosmetics. Int. J. Toxicol. 2019, 38, 5S-38S. [CrossRef]

5. Pocan, P.; Bahcegul, E.; Oztop, M.H.; Hamamci, H. Enzymatic hydrolysis of fruit peels and other lignocellulosic biomass as a source of sugar. Waste Biomass Valorization 2018, 9, 929-937. [CrossRef]

6. Trang, D.; Ngoc, L.; Anh, T.T. Antimicrobial and antioxidant activities of vine and leaf methanol extracts of Streptocaulon juventas (MeRR.). Can. Tho Univ. Sci. J. 2015, 40, 1-6. (In Vietnamese)

7. Wiegand, I.; Hilpert, K.; Hancock, R.E. Agar and broth dilution methods to determine the minimal inhibitory concentration (MIC) of antimicrobial substances. Nat. Protoc. 2018, 3, 75-163. [CrossRef] [PubMed]

8. Dutra, E.A.; Oliveira, D.A.G.; da Costa, E.; Kedor-Hackmann, E.R.M.; Santoro, M.I.R.M. Determination of the sun protection factor by spectrophotometry. Rev. Bras. Cienc. Farm. 2004, 40, 381-385.

9. Sayre, R.M.; Agin, P.P.; LeVee, G.J.; Marlowe, E. A comparison of in vivo and in vitro testing of sunscreening formulas. Photochem. Photobiol. 1979, 29, 559-566. [CrossRef]

10. Ruangtong, J.; Jiraroj, T.; T-Thienprasert, N.P. Green synthesized ZnO nanosheets from banana peel extract possess anti-bacterial activity and anti-cancer activity. Mater. Today Commun. 2020, 24, 101224. [CrossRef]

11. Larrosa, M.; García-Conesa, M.T.; Espín, J.C.; Tomás-Barberán, F.A. Ellagitannins, ellagic acid and vascular health. Mol. Asp. Med. 2010, 31, 513-539. [CrossRef] [PubMed]

12. Mokbel, M.S.; Hashinaga, F. Antibacterial and antioxidant activities of banana (Musa, AAA cv. Cavendish) fruits peel. Am. J. Biochem. Biotechnol. 2005, 1, 125-131. [CrossRef]

13. Rita, S.W.; Swantara, I.M.D.; Asih, I.A.R.A.; Puspawati, N.M. Antibacterial activity and antioxidant capacity of selected local banana peel (Musa sp.) methanol extracts cultivated in Bali. Int. J. Agric. Environ. Biores. 2020, 5, 242-251. [CrossRef]

14. Karo, R.M.; Manalu, P.; Sinurat, J.P. Antibacterial activity of flavonoid-rich fractions of Citrus maxima peel extract. Stannum: J. Sains dan Terap. Kim. 2020, 2, 16-21. [CrossRef]

15. Kapadia, S.P.; Pudakalkatti, P.S.; Shivanaikar, S. Detection of antimicrobial activity of banana peel (Musa paradisiaca L.) on Porphyromonas gingivalis and Aggregatibacter actinomycetemcomitans: An in vitro study. Contemp. Clin. Dent. 2015, 6, 496. [CrossRef] [PubMed]

16. Sun, T.; Ho, C.T. Antioxidant activities of buckwheat extracts. Food Chem. 2005, 90, 743-749. [CrossRef] 
17. Ali, M.; Rumpa, N.E.N.; Paul, S.; Hossen, M.; Tanvir, E.M.; Hossan, T.; Saha, M.; Alam, N.; Karim, N.; Khalil, M.; et al. Antioxidant potential, subacute toxicity, and beneficiary effects of methanolic extract of pomelo (Citrus grandis L. Osbeck) in long evan rats. J. Toxicol. 2019. [CrossRef]

18. Fidrianny, I.; Anggraeni, N.A.S.; Insanu, M. Antioxidant properties of peels extracts from three varieties of banana (Musa sp.) grown in West Java-Indonesia. Int. Food Res. J. 2018, 25, 57-64.

19. Castro-Vazquez, L.; Alañón, M.E.; Rodríguez-Robledo, V.; Pérez-Coello, M.S.; Hermosín-Gutierrez, I.; Díaz-Maroto, M.C.; Jordán, J.; Galindo, M.F.; Arroyo-Jimenez, M.D.M. Bioactive flavonoids, antioxidant behaviour, and cytoprotective effects of dried grapefruit peels (Citrus paradisi Macf.). Oxid. Med. Cell. Longev. 2016. [CrossRef]

20. Van Hung, P.; Yen Nhi, N.H.; Ting, L.Y.; Lan Phi, N.T. Chemical composition and biological activities of extracts from pomelo peel by-products under enzyme and ultrasound-assisted extractions. J. Chem. 2020. [CrossRef]

21. Abudayeh, Z.H.; Al Khalifa, I.I.; Mohammed, S.M.; Ahmad, A.A. Phytochemical content and antioxidant activities of pomelo peel extract. Pharmacogn. Res. 2019, 11, 244. [CrossRef]

22. Nichols, J.A.; Katiyar, S.K. Skin photoprotection by natural polyphenols: Anti-inflammatory, antioxidant and DNA repair mechanisms. Arch. Dermatol. Res. 2010, 302,71-83. [CrossRef] [PubMed]

23. Torres, A.E.; Luk, K.M.; Lim, H.W. Botanicals for photoprotection. Plast. Aesthet. Res. 2020, 7. [CrossRef]

24. Ratnasooriya, W.D.; Pathirana, R.N.; Dissanayake, A.S.; Samanmali, B.L.C.; Desman, P.K. Evaluation of in-vitro sun screen activities of salt marshy plants Suaeda monoica, Suaeda maritima and Halosarcia indica. Int. J. Pharm. Res. Allied Sci. 2016, 5, 15-20.

25. Sutar, M.P.; Chaudhari, S.R. Screening of in vitro sun protection factor of some medicinal plant extracts by ultraviolet spectroscopy method. J. Appl. Biol. Biotechnol. 2020, 8, 48-53.

26. Laeliocattleya, R.A.; Wijaya, J. The effect of sodium bisulfite immersion to the potential of Candi banana peel ethanol extract as radical scavenger and UV protection. IOP Conf. Ser. Earth Environ. Sci. 2019, 230, 012024. [CrossRef] 